\title{
Zirconium Zr 89 Df-IAB2M
}

National Cancer Institute

\section{Source}

National Cancer Institute. Zirconium Zr 89 Df-IAB2M. NCI Thesaurus. Code C111040.

A radioimmunoconjug ate comprised of an antibody fragment (IAB2M) against prostatespecific membrane antigen (PSMA), conjug ated to the chelator desferrioxamine (Df) and labeled with the radioisotope zirconium $\mathrm{Zr}$ 89, with potential positron emission tomography (PET) imaging activity. Upon administration of zirconium Zr 89 Df-IAB2M, the antibody moiety binds to the extracellular domain of PSMA expressed on cancer cells. This may enable PET detection of the radioisotope moiety, and allows the imaging and quantification of PSMA-expressing tumor cells. PSMA is a cell surface peptidase highly expressed by malignant prostate epithelial cells and vascular endothelial cells in various solid tumor malignancies. 